Proceedings

\title{
Rapeseed Post-Frying Oil from Fish Fillets as a Carbon Source in Microbial Oil Synthesis ${ }^{\dagger}$
}

\author{
Agata Fabiszewska *, Katarzyna Wierzchowska, Agnieszka Górska and Bartłomiej Zieniuk
}

Citation: Fabiszewska, A.;

Wierzchowska, K.; Górska, A.;

Zieniuk, B. Rapeseed Post-Frying Oil from Fish Fillets as a Carbon Source in Microbial Oil Synthesis.

Proceedings 2021, 70, 68. https:// doi.org/10.3390/foods_2020-07715

Published: 10 November 2020

Publisher's Note: MDPI stays neutral with regard to jurisdictional claims in published maps and institutional affiliations.

Copyright: (c) 2020 by the authors. Submitted for possible open access publication under the terms and conditions of the Creative Commons Attribution (CC BY) license (http://creativecommons.org/licenses/by/4.0/).

\author{
Department of Chemistry, Faculty of Food Sciences, Warsaw University of Life Sciences, 02-787 Warsaw, \\ Poland; katarzyna_wierzchowska1@sggw.edu.pl (K.W.); agnieszka_gorska@sggw.edu.pl (A.G.); \\ bartlomiej_zieniuk@sggw.edu.pl (B.Z.) \\ * Correspondence: agata_fabiszewska@sggw.edu.pl; Tel.: +48-22-59-37-621 \\ + Presented at the 1st International Electronic Conference on Food Science and Functional Foods, \\ 10-25 November 2020; Available online: https://foods_2020.sciforum.net/.
}

\begin{abstract}
Microbial oils, also called single-cell oils, are lipids synthesized by microorganisms exceeding $20 \%$ of the dry weight of the cell. The aim of this work was to investigate the possibility of applying a rapeseed post-frying oil from fish fillets as a carbon source in growth medium for Yarrowia lipolytica oleaginous yeast species in order to synthesize a microbial oil. The key contribution of this work is that the solution provides a sustainable method for valorization of post-frying waste oil. Shaken batch cultures were provided and the influence of triacylglyceride hydrolysis on yeast growth was evaluated. In conclusion, post-frying rapeseed oil seems to be an easily utilizable carbon source by yeast. Regardless of the method of lipid substrate pretreatment, the yeast strain preferentially accumulated oleic acid (C18: 1) from 52.07\% to $66.62 \%$ and linoleic acid (C18: 2) from 12.98\% to $24.10 \%$. To the best of our knowledge, this is the first report of using the oxygen nanobubbles as an unconventional method of aerating the culture medium containing lipid carbon sources. The use of water oxygenated with nano-sized bubbles to prepare culture media resulted in obtaining a higher yield of biomass compared to the biomass yield in distilled water-based medium.
\end{abstract}

Keywords: fatty acid; nanobubble; post-frying oil; single-cell oil; Yarrowia lipolytica

\section{Introduction}

Single-cell oils (SCOs) are edible oils stored in the cells of microorganisms [1]. The cost of microbiological oil production depends on the requirements of the selected oleaginous microorganisms and the culture parameters that should be ensured to achieve a satisfactory biomass yield and the level of lipid accumulation in the cells. According to Thevenieau and Nicaud [2], $60 \%-75 \%$ of the total cost of SCO biosynthesis is the cost of the raw material used as a carbon source. Considering the economic aspect, these costs can be reduced by using organic industrial wastes, including food industry wastes. The aim of this work was to investigate the possibility of applying a rapeseed post-frying oil from fish fillets as a carbon source in growth medium for Yarrowia lipolytica oleaginous yeast species in order to synthesize a microbial oil. The key contribution of this work is that the solution provides a sustainable method for valorization of post-frying waste oil.

\section{Materials and Methods}

\subsection{Chemical Compounds}

All chemicals were purchased from Sigma Aldrich (Saint Louis, USA). All medium ingredients were purchased from BTL (Łódź, Poland). Waste post-frying rapeseed oil was collected from a tank in the local fish factory located in Podlaskie Voivodeship in Poland. 


\subsection{Yeast Strain and Culture Conditions}

Y. lipolytica strain KKP 379 from the Collection of Industrial Microorganisms at the Prof. Wacław Dąbrowski Institute of Agricultural and Food Biotechnology in Warsaw (Poland) was used in the study. The strain was stored in cryovials containing ceramic beads with a cryoprotective agent at $-20^{\circ} \mathrm{C}$ (Protect Select, Technical Service Consultants Ltd., Heywood, UK).

Inoculation culture was grown for $20 \mathrm{~h}$ on a rotary shaker at $28^{\circ} \mathrm{C}$ in YP-G-2 medium, which contained $20.0 \mathrm{~g} / \mathrm{L}$ of glucose, $20.0 \mathrm{~g} / \mathrm{L}$ of peptone, and $10 \mathrm{~g} / \mathrm{L}$ of yeast extract. The media $\mathrm{pH}$ was 5.0. Experimental flask cultures were also provided on a rotary shaker (140 rpm) at $28{ }^{\circ} \mathrm{C}$ for $72 \mathrm{~h}$. Biomass yield was measured every $24 \mathrm{~h}$. "YP" and "S" media containing $2 \% w / w$ carbon source (glucose, olive oil, or rapeseed post-frying waste oil) were used. All "YP" media contained $10.0 \mathrm{~g} / \mathrm{L}$ of yeast extract and $20.0 \mathrm{~g} / \mathrm{L}$ of peptone. All "S" media contained $7.0 \mathrm{~g} / \mathrm{L}$ of $\mathrm{KH}_{2} \mathrm{PO}_{4}, 2.5 \mathrm{~g} / \mathrm{L}$ of $\left(\mathrm{NH}_{4}\right)_{2} \mathrm{SO}_{4}, 2.5 \mathrm{~g} / \mathrm{L}$ of $\mathrm{Na}_{2} \mathrm{HPO}_{4}, 0.16 \mathrm{~g} / \mathrm{L}$ of $\mathrm{FeSO}_{4} \times \mathrm{H}_{2} \mathrm{O}, 0.15 \mathrm{~g} / \mathrm{L}$ of $\mathrm{CaCl}_{2}, 0.08 \mathrm{~g} / \mathrm{L}$ of $\mathrm{MnCl}_{2} \times 4 \mathrm{H}_{2} \mathrm{O}, 0.02 \mathrm{~g} / \mathrm{L}$ of $\mathrm{ZnSO}_{4}, 2.0 \mathrm{~g} / \mathrm{L}$ of yeast extract, and $1.0 \mathrm{~g} / \mathrm{L}$ of peptone. The $\mathrm{pH}$ of the media was adjusted at 5.0 or 6.0 , respectively.

Two methods of substrate pretreatment were applied, which included incubation of waste oil in $3 \% w / v \mathrm{NaOH}$ or $3 \% w / v \mathrm{HCl}$ at $28^{\circ} \mathrm{C}$ or $70^{\circ} \mathrm{C}$ for $24 \mathrm{~h}$. Moreover, some culture media were prepared using fine bubbles water (fB), which was aerated with oxygen nanobubbles.

\subsection{Biomass Yield Determination}

Yeast biomass was characterized by cell dry mass measured by the thermogravimetric method. Cells were harvested by centrifugation ( $\left.8000 \mathrm{rpm}, 10 \mathrm{~min}, 4^{\circ} \mathrm{C}\right)$, washed in distilled water, and dried at $105^{\circ} \mathrm{C}$ until constant weight.

\subsection{Fatty Acid Profile Determination}

Cellular lipids were extracted and analyzed by the gas chromatography method according to Fabiszewska et al. [3]. Biomass for lipid extraction was harvested by centrifugation $\left(8000 \mathrm{rpm}, 10 \mathrm{~min}, 20^{\circ} \mathrm{C}\right)$, washed with distilled water, and dried at $80^{\circ} \mathrm{C}$. Extraction was performed in a Soxhlet extractor using $n$-hexane as a solvent.

\section{Results}

In the preliminary studies, cultures were conducted in glucose (YP-G-2) and olive oil (YP-O-2)-rich media, which were control cultures in relation to the medium with waste oil remaining after frying fish fillets (YP-WO-2) (Figure 1A). After $72 \mathrm{~h}$ of cultivation in the medium with the addition of post-frying rapeseed oil, the biomass yield reached 15.58 $\mathrm{g}_{\mathrm{d} . \mathrm{m} .} / \mathrm{dm}^{3}$. In the case of the YP-G-2 medium, it reached $13.71 \mathrm{gd.m} / \mathrm{dm}^{3}$ compared to culture in medium with olive oil (11.43 gd.m. $\left./ \mathrm{dm}^{3}\right)$.

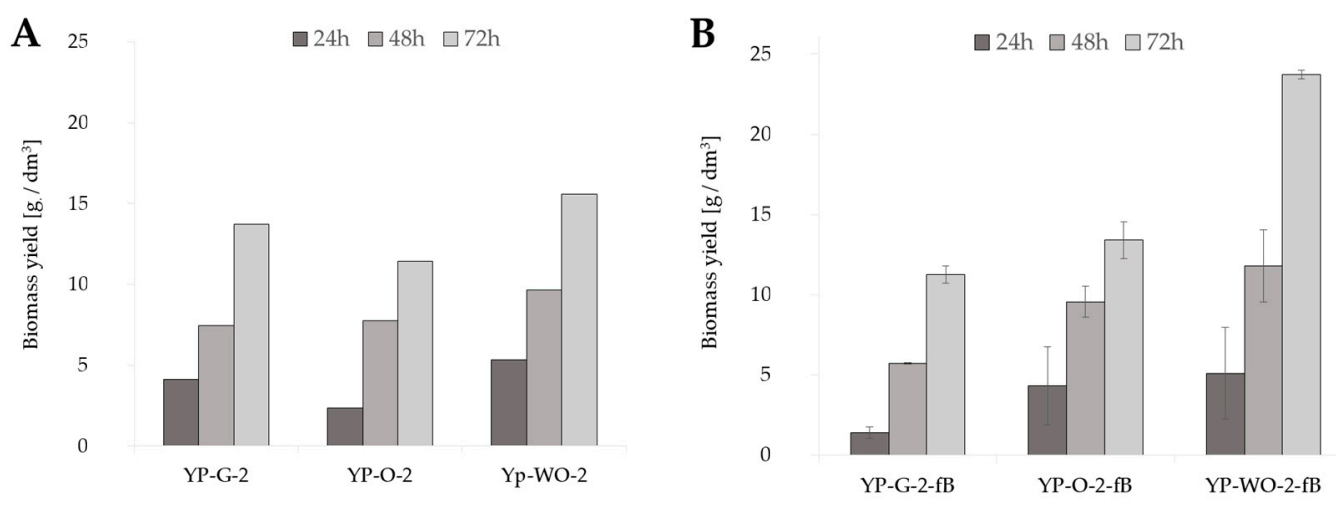




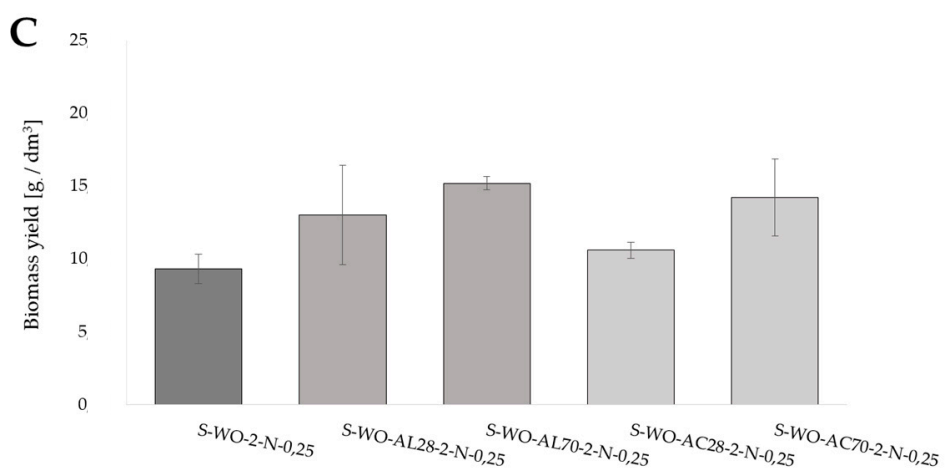

Figure 1. Biomass yield of $Y$. lipolytica yeast grown for $72 \mathrm{~h}$ in shaken cultures in (A) YP media with glucose (YPG-2), olive oil (YP-O-2), and waste oil (YP-WO-2) as a carbon source; (B) YP media prepared in water aerated with oxygen nanobubbles with glucose (YPG-2-fB), olive oil (YP-O-2-fB), and waste oil (YP-WO-2-fB) as a carbon source; (C) S-WO-2 media with waste rapeseed oil pretreated using Ac-acid hydrolysis or Al-alkaline hydrolysis at 28 or $70{ }^{\circ} \mathrm{C}$.

In the case of shaking flask cultures, the influence on yeast growth of the oxygenation of the water used during the preparation of culture medium was also investigated (Figure 1B). Two variants of medium were used: distilled water-based and "fine bubbles" waterbased. Additionally, in this experiment, three different carbon sources were used: glucose, olive oil, and post-frying waste oil. After the first day of cultivation, the amount of biomass in the medium with glucose, based on "fine bubbles" water (YP-G-2-fB), reached $1.38 \mathrm{gd.m} / \mathrm{dm}^{3}$. Other culture variants were characterized by higher biomass yields: 4.32 gd.m. $/ \mathrm{dm}^{3}$ for YP-O-2-fB medium and 5.10 gd.m. $/ \mathrm{dm}^{3}$ for YP-WO-2-fB medium, compared to control cultures after $24 \mathrm{~h}$. As a result, after $72 \mathrm{~h}$, the highest amount of biomass in the medium was achieved in cultures with post-frying waste $\left(23.73 \mathrm{gd.m} . / \mathrm{dm}^{3}\right)$.

The influence of waste oil pretreatment on the biomass yield in synthetic media with nitrogen source limitation (S), which stimulated yeast cells to lipid accumulation, was also evaluated (Figure 1C). The biomass yields after five days of culture, irrespective of the hydrolysis conditions, were higher than the biomass yield obtained in the control culture $\left(9.32 \mathrm{gd.m} . \mathrm{dm}^{3}\right)$. Moreover, the biomass yield differed in terms of the type of hydrolysis applied; it was higher in the case of hydrolysis in an alkaline environment under $28^{\circ} \mathrm{C}$ and $70{ }^{\circ} \mathrm{C}$.

In order to determine the effect of waste oil pretreatment by its hydrolysis on the final composition of obtained microbiological oils, the storage lipids were extracted from the yeast biomass cultured in a synthetic medium with non-hydrolyzed oil (Sp-Op-2) as a control medium and cultured in experimental media with the addition of post-frying waste oil hydrolyzed in an alkaline or acidic medium under various temperature conditions (Figure 2). For each of the SCO samples, the highest proportion of oleic acid (C18:1) was recorded in the total fatty acids contained in yeast extracted lipids. On the contrary, the microbiological oil containing the least oleic acid (C18:1) had the highest proportion of linoleic acid (C18:2) from the omega-6 family of acids (24.10\%). The lowest content of C18:2 was found in the microbial oil from the culture in the control medium-only $12.98 \%$. However, it had the highest percentage of nutritionally valuable linolenic acid (C18:3) $8.65 \%$. 

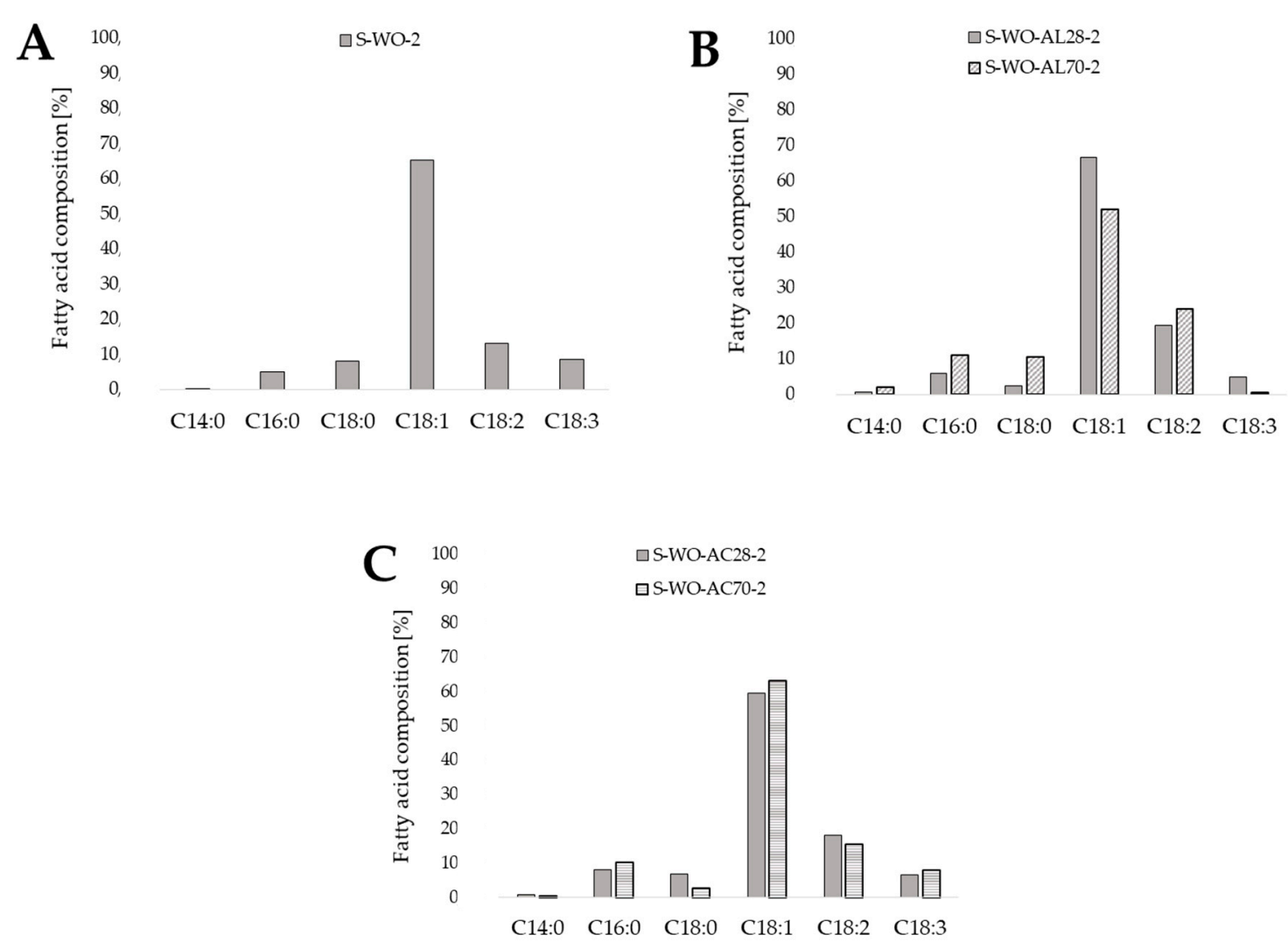

Figure 2. Composition of fatty acids in single cell oil extracted from yeast cells grown using synthetic medium S-WO-2 containing post-frying rapeseed oil as a carbon source (A) and waste oil pretreated under different conditions (Ac-acid hydrolysis (C) orAl-alkaline hydrolysis (B); 28 and 70 reflects to the temperature of hydrolysis) (content of fatty acids in relations to total fatty acids concentration, $\%)$.

\section{Discussion}

There are several studies in which an attempt has been made to utilize waste substrates from the fish industry by $Y$. lipolytica yeasts, including brine, sludge, and waste oil remaining after the smoking process [4,5]. Many ways of processing waste products to increase their assimilability by oily microorganisms, and thereby to improve the efficiency of the microbiological oil synthesis process, have been mentioned. The scientific literature lists a number of methods of waste pretreatment used to increase their assimilability by oleaginous microorganisms and, thus, to improve the efficiency of the microbiological oil synthesis. The pretreatment of waste products is mainly discussed in the context of plant origin wastes, generally referred to as lignocellulosic materials, not in the context of lipid waste [6-8]. In our own research, when acid hydrolysis was used, the biomass yield was higher when hydrolysis was performed at $70^{\circ} \mathrm{C}$. In the case of alkaline hydrolysis of waste oil, a similarly higher biomass yield was recorded for cultivation in a medium containing waste hydrolyzed at $70{ }^{\circ} \mathrm{C}$.

The water used to prepare the substrate in the experiment was aerated with oxygen nanobubbles. Nanobubbles are called spherical gaseous objects, dispersed in the volume of liquid, whose diameter does not exceed $1000 \mathrm{~nm}$ [9]. Their unique physical and mechanical properties, such as stability, large surface-to-volume ratio, and high internal pressure, have now made nanobubbles suitable for a wide range of applications in many industries, especially biotechnology and chemical wastewater treatment [10]. To date, there are no literature data on the culture of aerobic microorganisms in an oxygenated medium with such a dispersion. Considering the positive effect of nanobubble water on the growth 
of yeast, it is worth looking at the factors that may influence this phenomenon. The nanobubbles of oxygen allowed to separate possible impurities or to reduce the harmful effects of undesirable compounds present in post-frying oil, due to the nature of obtaining this source of carbon. Another hypothesis worth considering is the effect of nanobubble dispersion on the availability of lipid carbon sources for yeast cells. The intensive mixing that took place in the shake flasks experiment may have had a beneficial effect on the distribution of the lipid carbon source in the medium. The ability of gas bubbles used in the flotation method to adsorb on or around the surface of less "wettable" molecules could additionally influence the better use of selected components of the medium by yeast cells.

The results obtained show that regardless of the method of waste substrate treatment, the yeast strain preferred to accumulate oleic acid (C18:1) and linoleic acid (C18:2). The composition of the extracted lipids synthesized via the ex novo route may, to some extent, correspond to the composition of the lipid substrate [11]. The preferential accumulation of lipids by $Y$. lipolytica yeast results from their two transport systems depending on the length of the fatty acid chain. The first is specific to C12 and C14 acids, the second one to C16 and C18. C18 fatty acids are stored in the form of storage lipids, and the rest are used for current cell growth needs. The stored lipids can be used, among others, in the biotransformation processes to fatty acids absent in the lipid substrate [12]. Papanikolaou and Aggellis [13] proved that $Y$. lipolytica yeast cells absorb more oleic acid (C18:1) and linoleic acid (C18:2) than palmitic acid (C16:0) or stearic acid (C18:0), regardless of their initial concentrations.

Author Contributions: Conceptualization, A.F. and A.G.; methodology, A.F., K.W., A.G., and B.Z.; investigation, K.W.; resources, A.F.; writing-original draft preparation, A.F. and K.W.; writingreview and editing, A.G. and B.Z.; visualization, K.W.; supervision, A.F. All authors read and agreed to the published version of the manuscript.

Funding: This research received no external funding.

Institutional Review Board Statement: Not applicable.

Informed Consent Statement: Not applicable.

Data Availability Statement: Not applicable.

Acknowledgments: The authors gratefully acknowledge Karol Ulatowski (Faculty of Chemical and Process Engineering, Warsaw University of Life Sciences) for kindly delivering the oxygen nanobubbles water.

Conflicts of Interest: The authors declare no conflicts of interest.

\section{References}

1. Ratledge, C. Single Cell Oils for the 21st Century; AOCS Press: Champaign, IL, USA, 2010; doi:10.1016/B978-1-893997-73-8.500050 .

2. Thevenieau, F.; Nicaud, J.M. Microorganisms as sources of oils. Oilseeds Fats Crop. Lipids 2013, 20, D603, doi:10.1051/oc1/2013034.

3. Fabiszewska, A.; Pielińska, A.; Mazurczak, P.; Zieniuk, B.; Wołoszynowska, M. Impact of the selected factors on extraction yield and composition of fatty acids of microbial oil produced by the yeast cells of Yarrowia lipolytica. Żywność. Nauka. Technologia. Jakość. 2017, doi:10.15193/zntj/2017/110/173. (In Polish)

4. Fabiszewska, A.; Mazurczak, P.; Pielińska, A.; Zieniuk, B.; Nowak, D.; Białecka-Florjańczyk, E. Próba zastosowania drożdży Yarrowia lipolytica KKP 379 w zagospodarowaniu odpadów przemysłu rybnego. Postępy Tech. Przetwórstwa Spożywczego 2014, 2, 28-30. (In Polish)

5. Mazurczak, P.; Zieniuk, B.; Fabiszewska, A.; Nowak, D.; Woloszynowska, M.; Bialecka-Florjanczyk, E. Utylizacja odpadów pochodzących z zakładów przemysłu spożywczego i paliwowego z wykorzystaniem lipolitycznych drożdży Yarrowia lipolytica. Zesz. Probl. Postępów Nauk Rol. 2017, 588, 15-24. (In Polish)

6. Barlianti, V.; Dahnum, D.; Hendarsyah, H.; Abimanyu, H. Effect of alkaline pretreatment on properties of lignocellulosic oil palm waste. Procedia Chem. 2015, 16, 195-201, doi:10.1016/j.proche.2015.12.036.

7. Ghanavati, H.; Nahvi I.; Karimi, K. Organic fraction of municipal solid waste as a suitable feedstock for the production of lipid by oleaginous yeast Cryptococcus aerius. Waste Manag. 2015, 38, 141-148, doi:10.1016/j.wasman.2014.12.007.

8. Qin, L.; Liu, L.; Zeng, A.P.; Wei, D. From low-cost substrates to single cell oils synthesized by oleaginous yeasts. Bioresour. Technol. 2017, 245, 1507-1519, doi:10.1016/j.biortech.2017.05.163. 
9. Ulatowski, K.; Sobieszczuk, P.; Kuźmińsk, A.; Ciach, T. Badanie cytotoksyczności dyspersji nanopęcherzyków tlenu w wodzie. Acta Sci. Pol. Biotechnol. 2018, 17, 51-57. (In Polish)

10. Gurung, A.; Dahl, O.; Jansson, K. The fundamental phenomena of nanobubbles and their behavior in wastewater treatment technologies. Geosyst. Eng. 2016, 19, 133-142, doi:10.1080/12269328.2016.1153987.

11. Papanikolaou, S.; Chevalot, I.; Komaitis, M.; Aggelis, G.; Marc, I. Kinetic profile of the cellular lipid composition in an oleaginous Yarrowia lipolytica capable of producing a cocoa-butter substitute from industrial fats. Antonie Van Leeuwenhoek 2001, 80, 215224, doi:10.1023/A:1013083211405.

12. Saygün, A.; Şahin-Yeşilçubuk, N.; Aran, N. Effects of different oil sources and residues on biomass and metabolite production by Yarrowia lipolytica YB 423-12. J. Am. Oil Chem. Soc. 2014, 91, 1521-1530, doi:10.1007/s11746-014-2506-2.

13. Papanikolaou, S.; Aggelis, G. Selective uptake of fatty acids by the yeast Yarrowia lipolytica. Eur. J. Lipid Sci. Technol. 2003, 105, 651-655, doi:10.1002/ejlt.200300858. 